\title{
A THINKING PIECE. THE ROLE OF LANGUAGE IN EDUCATION FOR PEACE
}

\author{
SANAZ ETEMADIBOUSHERI ${ }^{1}$ \\ ${ }^{1}$ Korczak Centre in Rasht, Unit 7, 114 Street, Golsar Street, Rasht, Iran. ORCID: 0000-0002-7139-3257, \\ Email: sanny_e_b@yahoo.com
}

\begin{abstract}
Iran is a country of great ethnic diversity. Although the official language of the country is Farsi, more than 8 other languages and hundreds of dialects are spoken throughout the country. This great ethnic diversity has led to emergence and growth of different cultures and religions (both official and non-official). This great diversity has potential for cultural growth and development. In recent years, many non-governmental organizations have made great efforts to teach children peace in different ways. The biggest motivation for these trainings are: to end misbelieves toward education, and professing to equal citizenship rights for all the ethnic groups. In the past 20 years, the issue of the right to equal education has been a hot topic of discussion in most non-governmental children's researches. This refers to the promotion of peace culture, by peace-based educational programs for all age groups, from the beginning pre-school education stages. A group of active consultants and educational planners did a lot of work in this way. They held lots of workshops and meetings, and achieved successful programs with positive results.

KEYWORDS: culture of peace, ethnic group, ethnic diversity, non-governmental organizations, equal education
\end{abstract}




\section{INTRODUCTION}

My contribution is a thinking piece from an Iranian educational researcher, who works towards peace and intercultural dialog, aiming to create the best opportunities for children's rights development and hoping to enable them to flourish. In this paper I will discuss some of the efforts for peace relevant to my country but also in a wider context. For instance:

- Organizing educational trips to different regions of Iran and meeting with relatives and familiarizing them with the peace programs.

- Forming a literature group to collect stories based on peace and friendship and promoting these books in educational settings.

- Organizing celebrations for relatives to introduce their culture and traditions to others, and to get to know one another.

- Holding workshops in remote areas of Iran for parents and teachers.

After completing these workshops and meetings, results show that not all people think or share the same beliefs but can live a peaceful life by getting to know each other. Becoming familiar with other nations and taking interest in the lives of different people, has encouraged acceptance and created close friendships. Ultimately, this allows children to experience a safer and happier living environment. In order to achieve these values, the non-governmental organizations worked hard and selflessly, without any benefit or expectations.

In recent years, most non-governmental Iranian organizations have made great efforts to teach children the act of peace in various ways. The main motivation for having these trainings is to achieve the best possible solidarity and equal citizenship rights among Iranians.

Even though the differences between these ethnic groups led to conflict and oppression throughout history, most of these ethnicities all tend to value and promote education. As a result, for the past 20 years, the issue of the right to equal education has been a hot topic of discussion amongst most non-governmental children's research and educational organizations in Iran. Most of the experiences created and projects executed by these organizations have focused on the promotion of peace between nations, and peace-based educational programs for all age groups starting with children as young as pre-school level.

Children Research Institute is an independent, specialized, and non-governmental organization, which has been active in Iran since 1994 with the aim of Early Childhood Care and Development (ECCD). This institute was established with the efforts of a group of experts in education and training, academics, researchers, educators and the administrative staffs of educational centers for early childhood development. Since 1994, as active members of ECCD, we have undertaken several projects and programs throughout Iran with the participation of governmental and non-governmental departments, and international organizations. Due to the promotion of the holistic 
needs and support for young children from birth till the age of 15 , the institute was given a special promotional award by the Organization for the Promotion of Science. Many experiences are created through workshops and meetings that are held in most cities in Iran, which are organized by a group of active consultants and educational planners of active organizations.

\section{THE CREATION OF THE PEACE GROUP}

The creation of the peace group within children's research institute was aimed to organize all programs within the framework of co-existence, tolerance, acceptance and respect for all the differences, and the eradication of violence as a solution to problems.

"Peace must be taught from childhood" (Nassrinpay 2007), was the motto the group included in its agenda from the beginning, because if children learn peace-mindedness and Peace Culture, they will better play their part as peace promoters in the society as adults. During its first year, the Peace Group devoted time to the theoretical studies concerning peace and the identification of related areas. (Nassrinpay 2009) At the same time, the following activities were undertaken:

1. Collecting poems and songs with the theme of peace for the children.

2. Collecting stories and books with the theme of peace for children and compiling a list for kindergartens.

3. Identifying the rituals, beliefs and ceremonies that promote the concepts of co-existence, tolerance and arbitration.

4. Introducing peace defending national and international figures.

5. Distributing the statement by Federico Mayor, UNESCO Secretary-General, on the International Year of Tolerance on a wide scale.

Holding 28 meetings in 1999 and following the identification of various aspects of peace, the Peace Group drafted the Declaration of Peace Culture (Children's research of Donya 2006b).

\section{DECLARATION OF CULTURE OF PEACE}

The Declaration of Peace Culture, formulated in 15 sections, and stresses the need to respect the rights of refugees, senior citizens, children, women, and the disabled, and the need to protect the environment, cultural heritages, individual rights, freedom, and to avoid all kinds of violent behavior (Children's research of Donya 2006b). The Declaration addresses parents, educators, writers and experts in children's issues, and it urges and encourages them to teach Peace Culture to children while complying with the contents of the Declaration. We sent the Declaration to more than four thousand members of the institute, non-governmental organizations, kindergartens, newspapers, and also child related government centers all over the country (Children's re- 
search of Donya 2008).

The Declaration is one of the most lucid and clearly spelled out documents related to the teaching of Peace Culture, which understands peace through justice, freedom, equal rights of citizens, development, and the negation of war.

It has so far been printed in five prominent newspapers and in 23 general and special publications in Tehran and other cities. To date, 8,000 copies have been published and distributed.

\section{BOYCOTTING VIOLENCE PROVOKING TOYS}

In January 2000 we raised the question, of toys that provoked violence, for the first time in Iran. A declaration with six clauses was prepared by our group and distributed among educational centers for young children as well as the media.

In this document, it is recommended that families, instructors and caretakers of young children regard the boycotting of violence provoking toys as an effective way of controlling violent behavior (Children's research of Donya 2006).

The above-mentioned declaration was published in two official newspapers of the country as an important item.

On September 21, 2001, the International Peace Day, volunteer kindergartens in Tehran and other provinces collaborated to clear their premises of such toys.

On this day the children who brought their war making toys received gift toys provided by UNICEF.

143 kindergartens in 18 cities of the country were cleared of war toys on this day.

The activities of this program were:

1. Designing the badge of peace.

2. Preparing an introductory pamphlet on the preliminary steps to remove violent provoking toys.

\section{THE INTERNATIONAL DECADE FOR CULTURE OF PEACE NON-VIOLENCE FOR THE CHILDREN OF THE WORLD (2001-2010)}

Following the UN proclamation of 2001-2010 as the decade for Culture of Peace non-violence for the children of the world (and Rejection of Violence against Children), we more than any other institution in Iran, focused on this program.

On March $4^{\text {th }}, 2000$, in a coordinated plan, we held simultaneous events (same hour, same day) called "Proclaiming the Decade culture of peace non-violence for the children of the world" in 11 provinces. In this program, all colleagues, in collaboration with the representatives of the institute, traveled to different cities to introduce strategies and objectives to the participants.

Reading the Declaration culture of peace non-violence for the children of the world and our Announcement on the Decade were amongst the common programs in all the 11 cities. In each city, regional authorities also presented their views on Peace Culture (Children's research of Donya 2006b). 
Among the addressees of these sessions were parents, instructors and administrators, and others interested in issues concerning children who joined the authorities in these events. More than 6,000 participants took part in these coordinated and well-organized events from all over the country.

The objectives of these simultaneous events were:

1. Broadcasting the Decade of Peace Culture on a wide scale

2. Attracting the participation of all interested groups

3. Sensitizing government officials to Peace Culture

The program was well received in both national and local media.

\section{YOUNG PEOPLE PEACE GROUP}

With the development of our activities regarding Peace Culture, an experimental course was organized in 1999 for about 40 young persons between the ages of 14 and 17 years old (Children's research of Donya 2006b).

For one year the group met once a week with a group of specialists and followed the Living Value curriculum geared towards their needs.

During this one year, the group received workshop trainings on:

1. Living Values.

2. Universal Declaration of Human Rights.

3. Convention on the Rights of the Child.

4. Declaration of Peace Culture.

5. Convention on the Elimination of all forms of Discrimination against Women.

6. Convention on the Protection of Refugees.

7. Ethnic and religious groups in Iran.

Participants also took part in the following activities:

1. Visits to churches, synagogues and other worship places of Iran's religions.

2. Festivities of Iran's Armenians.

3. Ceremonies launching the Decade of Peace Culture.

4. The Day of Solidarity with Afghan Mothers.

By the end of the year 2000, two more groups (of about 60) participated in these programs. 


\section{The Day of Solidarity with Afghan Mothers}

Moreover, in August 2000 the children research institute for the first time held a program called the Day of Solidarity with Afghan mothers. On this day Afghan mothers exhibited their handicrafts, artworks and also their national foods.

The money collected from this program was given for the support of Afghan migrants kindergartens (Aminaee 2010).

\section{PUBLICATIONS RELATED TO PEACE CULTURE}

In February 2000 we produced a special publication on Peace Culture. The articles focused more than anything on Peace Culture and the need for education to promote and live by this important concept. The publication is considered to be one of the important sources for studies on Peace Culture.

\section{Council for the Development for Culture of Peace}

In May 2001 Children Research Institute sent the Declaration on the Elimination of Violence Provoking Toys to all non-governmental organizations active in small children issues. The Institute also forwarded a letter asking the organizations to sign the statement and form a group with the boycotting of violence provoking toys on its agenda.

An overall of 30 non-governmental organizations signed the declaration and officially started a new society called "Council for the Development of Peace Culture" (Children's research of Donya 2008).

The Council for the Development of Peace Culture held a seminar in October 2001 on "Peace, Children and Toys" for the first time in Iran. On this occasion, representatives of all organizations presented their views on children and peace. The council is at present active within the framework of the following work groups:

1. Research committee.

2. Family education committee.

3. Communication committee.

So far, each committee has planned and carried out several programs.

\section{PEACE IN THE AFTERNOON}

In order to widely introduce the Decade of Peace Culture, we arranged five afternoon programs which provided cultural, educational and recreational activities for children and their families (Yossefi 2009).

Amongst the objectives of this program were providing opportunities for family members to be together, introducing joyful, healthy and educational programs free from any kind of violence and introducing the fundamental concepts of peace.

A total of 4,000 people took part in this program in 2001. 
Due to the success of these afternoon events, we suggested that all non-governmental organizations to undertake the programs. In the summer of 2002, in 11 programs, more than 25 non-governmental organizations each week held several events for children and their families within the framework of peace, understanding and friendship. More than 10,000 people participated in these events. In other words, all participants declared solidarity with the programs of Peace Culture and of rejection of violence against children.

\section{CONCLUSIONS WITH OTHER ACHIEVEMENTS TOWARDS PEACE}

Peace had a political meaning in Iran's society, as a consequence of an eight-year war. Therefore, talk on peace could have somehow been perceived as a reflection on the country's strategic issues. The children's research institute's efforts since 1999 for drawing attention to Peace Culture has finally led to the extrication of the term "peace" from the red list and to its use by all sections of the community. Right now, many non-governmental organizations in their programs for children mention peace and benefit from it (Children's research of Donya 2005: 61, 98). We have attracted the support and cooperation of 30 non-governmental organizations for the development of Peace Culture within the framework of a common program called "The Council for the Development of Peace Culture among Children." We have attracted the participation of governmental departments for sustaining Peace Culture programs. As an example, today the Institute for the Intellectual Development of Children and Young People has undertaken the task of removing violence provoking toys in Iran (Children's research of Donya 2006b).

Another precious achievement of these years has been getting the support of families, teachers, instructors and child care-takers for Peace Culture programs. Iranian families are eager and ready to cooperate with and support the development of peace. We have created the mindset that peace should be learned from childhood, and along these lines we have mobilized many governmental departments and non-governmental organizations for the education of this concept to the children.

FUNDING: This research was funded by the UNESCO/Janusz Korczak Chair fellowship 2019 obtained through the Polish Commission for UNESCO

CONFLICT OF INTEREST: The author declares no conflict of interest.

ACKNOWLEDGMENTS: I would like to express my especial thanks and gratitude to my special professor: Anna Odrowaz-Coates, who enabled me to attend the $12^{\text {th }}$ UNESCO Janusz Korczak Chair International Summer School and Dr. Parvane Fakhamzadeh who has supported me in carrying out this research. Also special thanks to a distinguished professor of pedagogy in Iran Mrs. Touran Mirhadi who I had the honor of being her student, so I could get and benefit from her scientific and experimental knowledge and achievement. And finally, I would like to thank all of my dear students. They gave me the opportunity to teach them. 


\section{REFERENCES}

Aminaee, Akram. 2010. Educational queries in the culture of peace (Jostarhaye Amozashi Dar Farhange Solh). Tehran: Kargahe koodak publication.

Children's research of Donya. 2005. Health child pattern (Olghoye koodake Saalem): According to theories of Allport, Frankel, Fromm, Ragers, Maslow. Tehran: Gatreh publication.

Children's research of Donya. 2006. From Violence to Peace (Az Khoshonat Ta solh). Tehran: Karghah Koodak publication.

Children's research of Donya. 2006b. Documents for Children (Asnad Marbot Be Koodakan): Based on Convention On The Rights Of The Child And Declaration Of Peace Culture and Code Of Ethic. Tehran: Karghah Koodak publication.

Children's research of Donya. 2008. Previews of the Participatory Education Research Plan based on humanistic psychology. (Pish Pajoheshhaye Tarh Tahghighati Amozesh Mosharekati Mobtani Bar Ravanshenasi ensangara). Tehran: Karghah koodak publication.

Nassrinpay, Parichehr. 2007. Peace should be learned from childhood (Solh Ra Bayad Az Koodaki Amookht), Volume 1: An interview with Tooran Mirhadi and Nasser Yossefi. Tehran: Meshki publication.

Nassrinpay, Parichehr 2009. Peace should be learned from childhood (Solh Ra Bayad Az Koodaki Amookht, volume 2: An interview with Nooshafarin Ansari and Monir Poor Aslani (Homayoni) and Nassrin Mosaffa and Maryam Ahmadi. Tehran: Meshki publication.

Yossefi, Nasser. 2009. Training frees man (Amozesh Ensan Ra Azad Mikonad). Tehran: Karghahe Koodak publication.

\section{BIOGRAPHICAL NOTE}

Sanaz Etemadi Bousheri is an educational researcher at multiple NGOs dedicated to children and their wellbeing. To date she has been awarded UNESCO fellowships 3 times. At the moment she represents the newly established Korczak Centre in Rasht, Iran.

OPEN ACCESS: This article is distributed under the terms of the Creative Commons Attribution Non-commercial License (CC BY-NC 4.0) which permits any non-commercial use, and reproduction in any medium, provided the original author(s) and source are credited. 
